\title{
Profile of Open Cholecystectomy at Dr. Moewardi Hospital Surakarta January 2016 - December 2017 (Retrospective Study)
}

\section{Rakhman Wahyudi Mulyo', Agus Rahardjo², Muhammad David Perdana Putra ${ }^{1}$, Rico Alfredo Hutabarat $^{1 *}$, Pigur Agus Marwanto ${ }^{1}$}

${ }^{1}$ Resident of Surgery, Faculty of Medicine, Sebelas Maret University, Dr. Moewardi Hospital, Surakarta, Indonesia ${ }^{2}$ Consultant of Digestive Surgery, Department of Surgery, Sub Division of Digestive Surgery, Faculty of Medicine, Sebelas Maret University, Dr. Moewardi Hospital, Surakarta, Indonesia

\section{A R T I C L E I N F O \\ Keywords: \\ Cholelithiasis \\ Kolesistektomi}

\section{*Corresponding author: \\ Rico Alfredo Hutabarat \\ E-mail address: \\ ricoalfredohutabarat@gmail.com}

All authors have reviewed and approved the final version of the manuscript.

\section{https://doi.org/10.32539/bsm.v5i6.385}

\begin{abstract}
A B S T R A C T
Background. Cholelithiasis is a disease found in the general population throughout the world, and is influenced by several factors such as gender, age, and Body Mass Index. Gallstone disease is a common indication for surgery. The surgical procedure can be done in 2 ways, with an open cholecystectomy or laparoscopic cholecystectomy. Methods. This study was conducted on patients who were treated at the Regional General Hospital dr. Moewardi Surakarta from January 2016 to December 2017 with retrospective sampling. The patient's age, gender, weight, height, and length of stay were taken based on the data listed in the patient's medical record.

Results. A total of 96 patients, consisting of 61 (63.54\%) women and 35 (36.46\%) men who met the criteria for inclusion in this study. The age of the patients ranged from 31 to 86 years with a mean of 52.16 years. According to the age category, namely $<40$ years and 40 years, there were $14(14.58 \%)$ and $82(85.42 \%)$ people from all respondents, respectively. Only $26(27.1 \%)$ obese patients were found in this study. The mean length of post-operative hospitalization was $6.69 \pm 3.47$ days.

Conclusion. Gender and length of post-operative hospitalization in this study have characteristics that are in accordance with several previous studies.
\end{abstract}

\section{Introduction}

Gallstones are a combination of several elements that form a stone-like material that can be found in the gallbladder (cholecystolithiasis) or in the bile ducts (choledocholithiasis) or both. ${ }^{1}$ Gallbladder disease (GSD) including cholelithiasis is a disease which can be found in general population around the world. In the United States, the prevalence of GSD is about $10 \%$ of adults, and the number increases with age. ${ }^{2}$ The frequency of occurrence of gallstones increases 4 to 10fold after the age of 40 years. ${ }^{3}$ The female to male ratio is $4: 1.4$ Prevalence of GSD in Asia ranges from 4.35$10.7 \% .^{2}$ Study by Everhart et al. (2002) showed that the prevalence of gallstones in women was 10-20\% in India,
$5-12 \%$ in Taiwan, 5\% in China and Japan, and 4\% in Thailand. 5

Risk factors other than age and gender that play a role in the formation of gallstones are obesity, diabetes mellitus, and lipid profile abnormalities. 6 Gallstones are found in $25 \%$ of obese individuals. ${ }^{7}$ Obesity is associated with increased synthesis of cholesterol in the liver thereby increasing its secretion into bile. 8 Insulin resistance predisposes to gallstone formation with a similar mechanism, namely increasing cholesterol secretion from the liver, decreasing bile salt synthesis, and/or interfering with gallbladder motility. Gallstone formation is also influenced by low HDL 
levels, hypertriglyceridemia, and high homocysteine levels. 6

Gallstone disease is a common indication for surgery. The surgical procedure can be performed in 2 ways, with open cholecystectomy or laparoscopic cholecystectomy.9 The open cholecystectomy procedure is one of the competencies that must be mastered by a surgical resident and is included in the curriculum of surgeon education.

\section{Material and Methods}

The study was conducted on open cholecystectomy patients who were treated at the Regional General
Hospital dr. Moewardi Surakarta from January 2016 to December 2017 with retrospective sampling.

Samples were taken from the patient's medical record data and recorded patient data which included identity, gender, age, weight, height, and length of treatment period after surgery.

\section{Result}

From the results of the medical record, it was obtained a sample of 96 patients, consisting of 61 (63.54\%) female and 35 (36.46\%) male who met the criteria for entering this study.

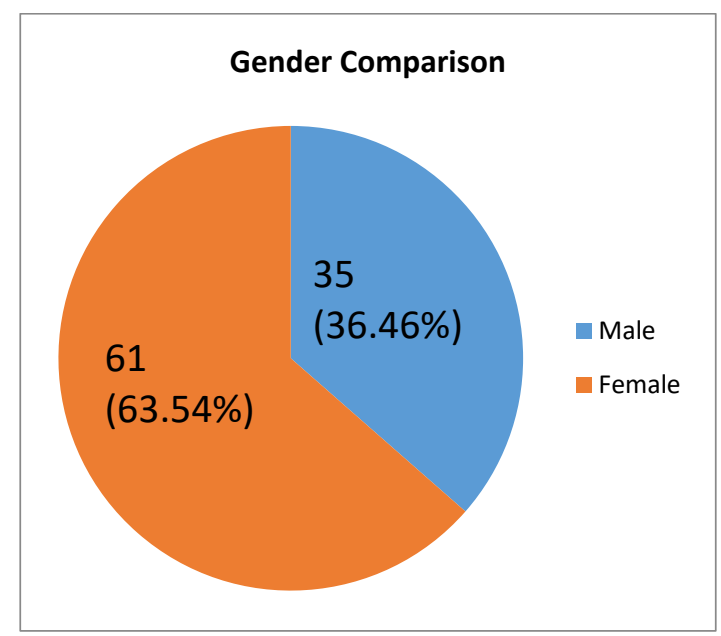

Figure 1. Gender Category Chart

Patient characteristics such as mean age, Body hospitalization showed in Table 1. Mass Index (BMI), and length of post-operative

Table 1. Sample Characteristics (n=96)

\begin{tabular}{ll}
\hline Characteristics & Value \\
\hline Age (years), mean \pm SD & $52.17 \pm 11.95$ \\
Gender & \\
$\quad$ Male, n $(\%)$ & $65(36.46 \%)$ \\
$\quad$ Female, n (\%) & $23.43 \pm 4.60$ \\
BMI $\left(\mathrm{kg} / \mathrm{m}^{2}\right)$, mean $\pm \mathrm{SD}$ & $70(72.92 \%)$ \\
$\quad$ Non-obese, n (\%) & $26(27.08 \%)$ \\
$\quad$ Obese, n (\%) & \\
Length of hospitalization & $6.69 \pm 3.47$ \\
Post-Operative (days), mean $\pm \mathrm{SD}$ &
\end{tabular}

\section{SD: standard deviation}

The mean of patients' Body Mass Index (BMI) was $23.43 \pm 4.60 \mathrm{~kg} / \mathrm{m} 2$ with 70 (72.92\%) patients included in non-obese group. The patients' BMI was further categorized in more detail according to WHO Asia-Pacific criteria.
The age of the patients ranged from 31 to 86 years. According to the age category, namely $<40$ years and $\geq 40$ years, there were 14 (14.58\%) and $82(85.42 \%)$ people from all respondents, respectively. 


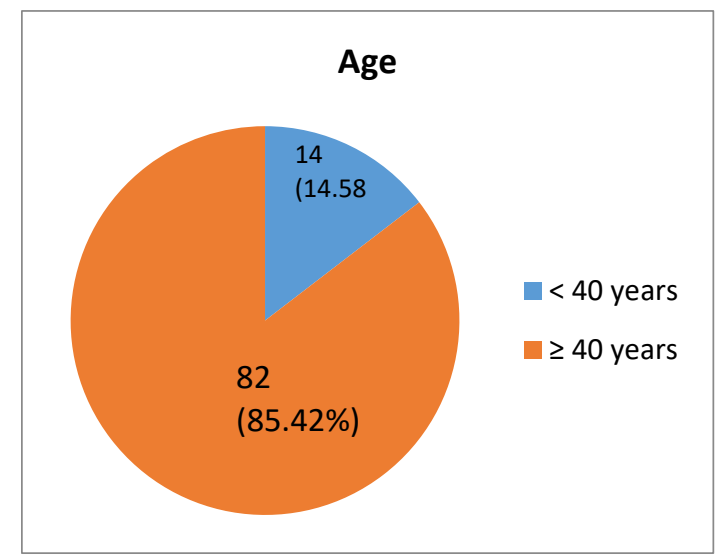

Figure 2. Patient Age Category Chart

The category of Body Mass Index (BMI) according to patients based on their obesity status. WHO Asia-Pacific classification was used to classify

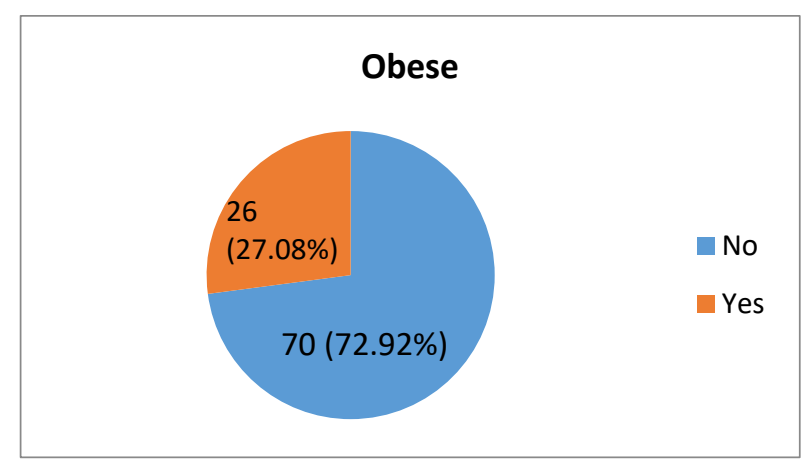

Figure 4. Obesity Status Category Chart

The mean length of postoperative hospitalization was $6.69 \pm 3.47$ days. Based on these results, the sample was categorized based on the length of postoperative hospitalization $\leq 6$ days and $>6$ days.

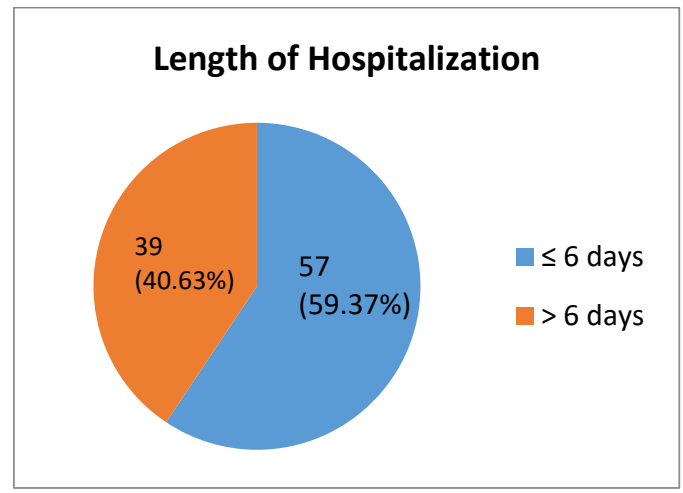

Figure 5. Post-operative Length of Hospitalization Category Chart

\section{Discussion}

In this study, there were more female patients than male patients $(63.5 \%$ vs. $36.5 \%)$. The same thing was also found in a study by Sueta and Warsinggih ${ }^{10}$ at the Makassar Hospital which showed that gender was significantly associated with the incidence of gallstones $(p=0.001)$. The presence of female hormones, namely estrogen, is one of the reasons for the increasing number of female patients. Estrogen plays a role in cholelithiasis because its ability to stimulate hepatic lipoprotein receptors, thereby increasing cholesterol uptake from the diet and biliary secretion. ${ }^{11}$

The age of the patients ranged from 31 to 86 years with a mean of 52.16 years. According to the age category, namely $<40$ years and $\geq 40$ years, there were $14(14.58 \%)$ and $82(85.42 \%)$ people from all 
respondents, respectively. In previous studies, there were controversial results regarding the relationship between age and the incidence of gallstones. One study showed a significant association $(\mathrm{p}=0.008)$ between the age group less than 40 years and the incidence of gallstones ${ }^{10}$, while another study showed that the prevalence of gallstones increased with age, peaking in the sixth decade. ${ }^{12}$ In this study, 75 (78.1\%) patients were patients under 60 years.

Only 26 patients (27.1\%) were obese in this study. A study stated that obesity is a potential risk for gallstones 4 times greater than people who are not obese, with the number of obese cholelithiasis patients than without obesity (97 vs 17 people). ${ }^{10}$ In line with this study, the study by Sodhi et $a^{12}$ showed that increased BMI is a risk factor for gallstone formation. This may be because obesity increases biliary cholesterol. Obesity is also associated with increased synthesis of cholesterol in the liver, thereby increasing its secretion into bile.

The average length of stay for post cholecystectomy patients in this study was $6.69 \pm 3.47$ days. The study by Harrison et $\mathrm{al}^{13}$ showed the mean length of stay after cholecystectomy was 2.99 days in a small hospital, 3.09 days in a medium hospital, and 2.59 days in a large hospital. Meanwhile, a study conducted in Semarang, Indonesia showed that the average length of hospitalization after cholecystectomy ranged from 2-7 days (mean $4.79 \pm 1.18$ ) days. Rooh-ul-Muqim et al (2008) stated that the average length of hospitalization for post-open cholecystectomy was 3.93 days. ${ }^{9}$

\section{Conclusion}

In this study, several characteristics of cholelithiasis patients who underwent an open cholecystectomy procedure at Dr. Moewardi January 2016 - December 2017 were obtained such as age, gender, Body Mass Index, and length of post-operative hospitalization. Gender and length of post-operative hospitalization in this study have characteristics that are in accordance with several previous studies.

\section{References}

1. Doherty GM. Biliary Tract. In : Current
Diagnosis \& Treatment Surgery 13th edition. 2010. US : McGraw-Hill Companies,p544-55.

2. Getachew A. Epidemiology of gallstone disease in Gondar University Hospital, as seen in the department of radiology. Ethiop J Health Dev 2008; 22(2):206-11

3. Shaffer EA. Epidemiology and risk factors for gallstone disease: has the paradigm changed in the 21 st century? Curr GastroenterolRep 2005;7:132-140.

4. Schirmer BD, Winters KL, Edlich RF. Cholelithiasis and cholecystitis.J Long Term Eff Med Implants. 2005; 15(3):329-38.

5. Everhart JE, Yeh F, Lee ET, et al. Prevalence of gallbladder disease in American Indian populations: findings from the Strong HeartStudy. Hepatology 2002;35:1507-1512.

6. Stinton LM, Ghaffer EA. Epidemiology of Gallbladder Disease: Cholelithiasis and Cancer. Gut liver 2012;6:172-87.

7. Li VK, Pulido N, Fajnwaks P, Szomstein S, Rosenthal R, Martinez- Duartez P. Predictors of gallstone formation after bariatric surgery: a multivariate analysis of risk factors comparing gastric bypass, gastric banding, and sleeve gastrectomy. Surg Endosc2009;23:1640-1644.

8. Lambou-Gianoukos S, Heller SJ. Lithogenesis and bile metabolism.Surg Clin North Am 2008;88:1175-1194.

9. Muqim R-U, Afridi FG, Iqbal J, Akbar J, Khan $Z$, Zarin M, et al. Comparison in Terms of Postoperative Morbidity and Hospital Stay between Open Cholecystectomy and Laparoscopic Cholecystectomy. World Journal of Laparoscopic Surgery with DVD. 2008;:1721.

10. Sueta MAD, Warsinggih. Faktor risiko terjadinya batu empedu di RSUP Dr. Wahidin Sudirohusodo Makassar. Jurnal Bedah Nasional. 2017Jan;1(1):20-6.

11. Putri F, Indrasari ND. Gallstone Analysis. The Indonesian Journal of Gastroenterology, Hepatology and Digestive Endoscopy; 2016;17: 124-130. 
12. Sodhi JS, Zargar SA, Khateeb S, et al. Prevalence of gallstone disease in patients with type 2 diabetes and the risk factors in North Indian population: A case control study. Indian Journal of Gastroenterology; 2014;33: 507511.

13. Harrison EM, O’Neill S, Meurs TS, Wong PL, Duxbury M, Paterson-Brown S, Wigmore SJ, Garden OJ. Hospital volume and patient outcomes after cholecystectomy in Scotland: retrospective, national population based study. BMJ. 2012;344:e3330. 